\title{
Switching Hedgehog inhibitors and other strategies to address resistance when treating advanced basal cell carcinoma
}

\author{
Hung Q. Doan ${ }^{1,2}$, Leon Chen ${ }^{3}$, Zeena Nawas ${ }^{4}$, Heng-Huan Lee ${ }^{5}$, Sirunya Silapunt ${ }^{2}$ \\ and Michael Migden ${ }^{1,2,6}$ \\ ${ }^{1}$ Department of Dermatology, Division of Internal Medicine, The University of Texas MD Anderson Cancer Center, Houston, \\ TX, USA \\ ${ }^{2}$ Department of Dermatology, University of Texas McGovern Medical School, Houston, TX, USA \\ ${ }^{3}$ US Dermatology Partners, Houston, TX, USA \\ ${ }^{4}$ Department of Dermatology, Baylor College of Medicine, Houston, TX, USA \\ ${ }^{5}$ Department of Molecular and Cellular Oncology, The University of Texas MD Anderson Cancer Center, Houston, TX, USA \\ ${ }^{6}$ Departments of Dermatology and Head and Neck Surgery, The University of Texas MD Anderson Cancer Center, Houston, \\ TX, USA
}

Correspondence to: Hung Q. Doan, email: hqdoan@mdanderson.org

Keywords: basal cell carcinoma; Hedgehog pathway inhibitor; resistance; switching; combination therapy

Received: July 14, 2021

Accepted: August 28, 2021

Published: September 28, 2021

Copyright: ๑ 2021 Doan et al. This is an open access article distributed under the terms of the Creative Commons Attribution License (CC BY 3.0), which permits unrestricted use, distribution, and reproduction in any medium, provided the original author and source are credited.

\section{ABSTRACT}

Although basal cell carcinoma (BCC) is often managed successfully with surgery, patients with locally advanced BCC (laBCC) or metastatic BCC ( $\mathrm{mBCC}$ ) who are not candidates for surgery or radiotherapy have limited treatment options. Most BCCs result from aberrant Hedgehog pathway activation in keratinocyte tumor cells, caused by sporadic or inherited mutations. Mutations in the patched homologue 1 gene that remove its inhibitory regulation of Smoothened homologue (SMO) or mutations in SMO that make it constitutively active, lead to Hedgehog pathway dysregulation and downstream activation of GLI1/ 2 transcription factors, promoting cell differentiation and proliferation. Hedgehog inhibitors (HHIs) block overactive signaling of this pathway by inhibiting SMO and are currently the only approved treatments for advanced BCC. Two small-molecule SMO inhibitors, vismodegib and sonidegib, have shown efficacy and safety in clinical trials of advanced BCC patients. Although these agents are effective and tolerable for many patients, HHI resistance occurs in some patients. Mechanisms of resistance include mutations in SMO, noncanonical cell identity switching leading to tumor cell resistance, and non-canonical pathway crosstalk causing Hedgehog pathway activation. Approaches to managing HHI resistance include switching HHIs, HHI and radiotherapy combination therapy, photodynamic therapy, and targeting Hedgehog pathway downstream effectors. Increasing understanding of the control of downstream effectors has identified new therapy targets and potential agents for evaluation in BCC. Identification of biomarkers of resistance or response is needed to optimize HHI use in patients with advanced BCC. This review examines HHI resistance, its underlying mechanisms, and methods of management for patients with advanced BCC.

\section{INTRODUCTION}

Basal cell carcinoma $(\mathrm{BCC})$ is the most common keratinocyte tumor and human malignancy worldwide $[1,2]$. In the United States, the overall lifetime risk of developing $\mathrm{BCC}$ is estimated to be at least $20 \%$; the incidence rate and the associated healthcare costs increase annually [3]. Major risk factors for the development of BCC include age and ultraviolet light exposure [3]. Most cases of BCC are treated surgically, which typically 
has an excellent prognosis $[4,5]$. Standard excision or curettage and electrodessication are often used for lowrisk lesions, and Mohs micrographic surgery is often effective for treating high-risk tumors [4]. However, a subset of advanced BCC cases that includes both locally advanced $\mathrm{BCC}(\mathrm{laBCC})$ and metastatic $\mathrm{BCC}(\mathrm{mBCC})$ are not amenable to surgery due to high morbidity and risk for severe disfigurement $[1,6]$.

The majority of BCCs have aberrant activation of the Hedgehog signaling pathway, most often from inactivating mutations in a negative regulator, patched homologue 1 (PTCH1), or less often from activating mutations in a positive regulator, Smoothened homologue $(S M O)$ [7, 8]. Dysregulation of the Hedgehog signaling pathway leads to activation of transcription by the transcription factors GLI1 and GLI2 (Figure 1) [9]. In keratinocytes, the Hedgehog signaling pathway controls cell differentiation and proliferation to maintain cutaneous stem cell populations and regulate the development of sebaceous glands and hair follicles [10].

Hedgehog pathway inhibitors (HHIs) are the only US Food and Drug Administration (FDA)-approved pharmacologic treatment for patients with advanced BCC [4]. Vismodegib (Erivedge ${ }^{\circledR}$, Genentech Inc., South San Francisco, CA) and sonidegib $\left(\right.$ ODOMZO ${ }^{\circledR}$, Sun Pharmaceutical Industries, Inc., Cranbury, NJ, USA) are two oral HHIs indicated for the treatment of adults with laBCC following surgery or radiation therapy or for those who are not candidates for surgery or radiation therapy $[11,12]$. Vismodegib is also indicated for the treatment of adults with $\mathrm{mBCC}$ in the US [12]. These agents are small molecule inhibitors of SMO that prevent the activation of GLI1 and GLI2.

The efficacy and safety of vismodegib was investigated in three main clinical trials: the ERIVANCE study, the STEVIE study, and the MIKIE study [13-15]. Sonidegib was evaluated in the phase 2 BOLT clinical trial at $6,12,30$, and 42 months [16-19].

The phase 2, multicenter, international, nonrandomized ERIVANCE study (NCT00833417) evaluated a continuous regimen of vismodegib $150 \mathrm{mg} /$ day in 63 patients with laBCC and 33 patients with mBCC [13]. In the primary analysis, objective response rate (ORR) by independent review, was $43 \%$ for patients with laBCC and $30 \%$ for patients with $\mathrm{mBCC}$; in both cohorts, most patients had tumor shrinkage. The most common grade 3-4 adverse events (AEs) were muscle spasms, weight loss, fatigue, and loss of appetite; the rate of discontinuation due to AEs was $12 \%$ [13].

The STEVIE study (NCT01367665), a phase 2, single-arm, multicenter, international, non-randomized, open-label study, evaluated vismodegib in elderly patients (median age of 72 years) with a high incidence of comorbidities - a population similar to clinical practice. Patients with laBCC $(n=1119)$ or $\operatorname{mBCC}(n=$ 96) received vismodegib $150 \mathrm{mg} /$ day [14]. The primary endpoint was safety. The most common treatmentemergent AEs (TEAEs; $\geq 20 \%$ of patients) were muscle spasms, alopecia, dysgeusia, and decreased weight, similar to the profile observed in ERVIANCE [13, 14]. Vismodegib exposure $\geq 12$ months did not result in increased incidence or severity of TEAEs, and the rate of discontinuation due to TEAEs was $31 \%$. Among patients with measurable disease at baseline, investigator-assessed responses occurred in $68.5 \%$ of patients with laBCC and $36.9 \%$ of patients with $\mathrm{mBCC}$ [14].

The randomized, double-blind, regimencontrolled, intermittent dosing, phase 2 MIKIE study (NCT01815840), investigated vismodegib in adult patients with multiple BCCs amenable to surgery, as well as patients with basal cell nevus syndrome [15]. Patients were randomized $1: 1$ to treatment A (150 mg oral vismodegib once daily for 12 weeks, followed by three rounds of 8 weeks of placebo daily, then 12 weeks of 150 mg vismodegib once daily $[n=116])$ or treatment $\mathrm{B}$ (150 $\mathrm{mg}$ oral vismodegib once daily for 24 weeks, then three rounds of 8 weeks of placebo daily followed by 8 weeks of $150 \mathrm{mg}$ vismodegib once daily [ $n=113]$ ) [15]. The primary endpoint was percent reduction from baseline in clinical BCCs at week 73 [15]. Mean percent reduction in BCCs from baseline to the end of the study was $62.7 \%$ (95\% confidence interval [CI] 53.0-72.3) and 54.0\% (43.6-64.4) for treatment groups A and B, respectively. [15] Overall, $94 \%$ and $97 \%$ of patients in treatment groups $\mathrm{A}$ and $\mathrm{B}$, respectively, experienced TEAEs, while the most common AEs grade 3 or greater included muscle spasms, increased blood creatine phosphokinase, and hypophosphatemia [15].

The safety and efficacy of sonidegib, another FDAapproved $\mathrm{HHI}$ for advanced BCC, was evaluated in the phase 2, multicenter, randomized, double-blind BOLT clinical study (NCT01327053) [11, 16-19]. Patients with laBCC not amenable to surgery or radiotherapy or $\mathrm{mBCC}$ received sonidegib $200 \mathrm{mg}(n=79)$ or $800 \mathrm{mg}$ $(n=151)$ once daily. In the primary analysis, the primary endpoint, ORR by central review, was $43 \%$ vs $15 \%$ for laBCC and $\mathrm{mBCC}$, respectively, in the 200-mg group, and $38 \%$ vs $17 \%$, respectively, in the $800-\mathrm{mg}$ group [19]. The most common AEs included muscle spasms, dysgeusia, alopecia, and nausea. The most common AEs leading to treatment discontinuation were muscle spasm, dysgeusia, weight decrease, and nausea [16-19].

Other HHIs under investigation in advanced BCC include patidegib, itraconazole, and arsenic trioxide. Patidegib has orphan drug and breakthrough therapy designations from the FDA and an orphan drug designation from the European Medicines Agency as a topical agent for Gorlin syndrome, also known as nevoid basal cell carcinoma syndrome, a rare genetic form of $\mathrm{BCC}$ characterized by mutations in PTCH1 resulting in multiple BCCs [20, 21]. Patidegib is being studied in a phase 3 trial for the reduction of disease burden in Gorlin 
syndrome (NCT03703310) and in a phase 2 trial of nonGorlin high frequency BCC (NCT04155190). Itraconazole binds to SMO at a site distinct from the other HHIs [22]. Arsenic trioxide destabilizes GLI2 to inhibit transcription of target genes of the Hedgehog signaling pathway and has shown activity in combination with itraconazole in $\mathrm{BCC}$ refractory to vismodegib or both vismodegib and sonidegib [23].

Despite the reported excellent overall efficacy of and safety profile for treatment with vismodegib and sonidegib, some patients demonstrate tumor intrinsic resistance to $\mathrm{HHI}$ treatment or develop resistance during treatment. This review will discuss HHI resistance, its underlying mechanisms, and methods of management for patients with advanced BCC.

\section{Hedgehog inhibitor resistance in clinical studies and practice}

Results from clinical studies of vismodegib and sonidegib show proportions of patients with advanced
$\mathrm{BCC}$ resistant to treatment (intrinsic resistance) and who develop resistance to treatment after an initial response (acquired resistance). Case studies from clinical practice provide further descriptions on lack of response, partial response, and development of resistance after an initial response to an $\mathrm{HHI}[24,25]$.

In the primary analysis of the ERIVANCE study, the rate of progressive disease (PD) with vismodegib treatment was $13 \%$ and $3 \%$ for $\mathrm{laBCC}$ and $\mathrm{mBCC}$, respectively [13]. In both cohorts, median progressionfree survival (PFS) was 9.5 months, and median duration of response was 7.6 months [13]. At data cutoff ( 9 months after last patient enrolled), 10 of 13 patients who had a complete response did not have disease progression. Disease progression was the most common reason for discontinuation of vismodegib among patients with $\mathrm{mBCC}$ $(18 \%) ; 7 \%$ of patients with laBCC also discontinued treatment for that reason [13].

In the primary analysis of the BOLT study, the rate of $\mathrm{PD}$ for patients receiving sonidegib $200 \mathrm{mg}$ was $10 \%$ for $\mathrm{laBCC}$ and $8 \%$ for $\mathrm{mBCC}[19]$. Median PFS

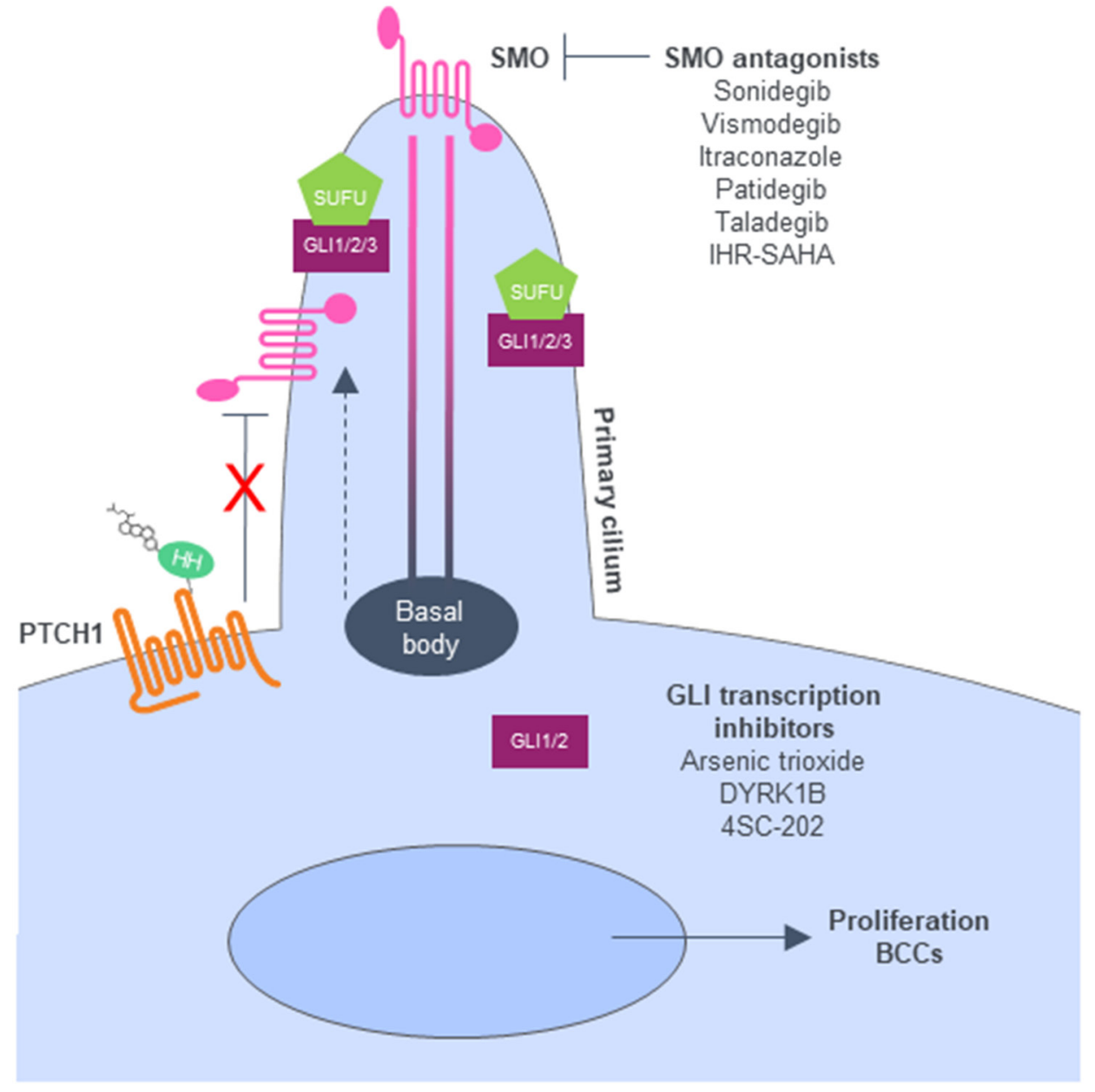

Figure 1: Hedgehog signaling pathway. When the HH ligand is present, Ptch1 is inactivated and allows SMO to move to the top of the cilia, triggering downstream signals and GLI activation. Adapted from [82]. Abbreviations: BCC: basal cell carcinoma; DYRK1B: dualspecificity-tyrosine-phosphorylation-regulated kinase 1B; GLI: glioma-associated oncogene; HH: Hedgehog; Ptch1: Patched-1; SMO: Smoothened; SUFU: Suppressor of fused. 
was not reached in patients with laBCC and was 13.1 months in patients with $\mathrm{mBCC}$ in the 200-mg group; it was not reached in patients with laBCC and was 7.6 months in patients with $\mathrm{mBCC}$ in the $800-\mathrm{mg}$ group. Median duration of tumor response was not reached for either disease cohort with sonidegib $200 \mathrm{mg}$ or for patients with laBCC in the 800-mg group, and was 8.3 months for patients with $\mathrm{mBCC}$ in the $800-\mathrm{mg}$ group [19]. At the 12-month analysis, $29.1 \%$ of patients receiving sonidegib $200 \mathrm{mg}$ and $9.9 \%$ of patients receiving sonidegib $800 \mathrm{mg}$ discontinued treatment due to PD [17].

A case report described an elderly man with recurrent laBCC invading his right orbit and frontal sinus after excision and radiation therapy [25]. After 1 year of treatment with vismodegib $150 \mathrm{mg} /$ day, the lesion initially decreased in the nasal region, but later progressed in the orbital region and upper cheek [25]. After receiving treatment with vismodegib for a total of 28 months, molecular analysis of tumor tissue revealed a mutation in PTCH1 but no mutation in SMO [25]. After discontinuing vismodegib treatment, he developed $\mathrm{mBCC}$. Thus, BCCs may exhibit intratumoral heterogeneity and may acquire mutations during treatment that confer HHI resistance [25].

Some patients develop resistance after an initial response to an HHI [26-28]. In the STEVIE study, a 59-year-old man with Gorlin syndrome responded to vismodegib $150 \mathrm{mg} /$ day and achieved a reduction in size and in number of BCCs, until clinically undetectable, and a disappearance of palmar pits. After 3 years of continuous vismodegib treatment, three lesions appeared ( 2 histologically confirmed as BCC recurrence), and treatment was discontinued per study protocol. Within 2 months, multiple recurrences were observed at the original locations. Molecular analysis of the two excised BCCs showed a germline mutation in $\mathrm{PTCH} 1$ and a mutation in $S M O$ known to cause vismodegib resistance [26].

Although biomarkers of HHI resistance have not been identified, hair regrowth may be an early marker of HHI resistance based on observations in a 65-yearold female with Gorlin syndrome and a 56-year-old male with laBCC. Each had a partial response to vismodegib and alopecia as a treatment side effect. After being progression-free on long-term continuous vismodegib treatment, each patient experienced disease progression. In addition, each patient had reversal of alopecia within 2 months of disease progression, suggesting resistance to vismodegib allowed for sufficient Hedgehog pathway signaling to reverse the alopecia and enable tumor growth [29].

\section{Mechanisms of Hedgehog inhibitor resistance}

HHI resistance may develop via disruption of the HHI binding site through SMO mutations, which differentially modulate the activity of HHIs depending on changes in SMO structure [30-32]. In vitro binding site kinetics of vismodegib and other SMO antagonists (with the same binding site) differed between wild type $S M O$ and a frequently identified SMO mutant (D473H) known to cause vismodegib resistance; moreover, these binding differences may provide an explanation for sensitivity to D473H and SMO D473H inhibitory activity [31].

Most patients with HHI-resistant BCC have mutations in $S M O$, regardless of whether resistance is intrinsic or acquired [33-35]. Molecular analysis of tumors from two vismodegib-resistant patients enrolled in the STEVIE study - one with intrinsic resistance and one with acquired resistance - showed the patient with intrinsic resistance had an SMO G497W mutation known to interfere with drug entry to the binding site, and the patient with acquired resistance had an SMO D473Y mutation known to interfere directly with vismodegib binding affinity [35]. Analysis of SMO mutations identified in $50 \%$ of SMO inhibitor-resistant BCCs demonstrated two distinct mechanisms of resistance: binding site mutations, observed in patients with acquired resistance, or mutations releasing SMO autoinhibition to confer constitutive SMO activity, observed in patients with intrinsic and acquired resistance [36]. Concurrent, non-SMO mutant forms of resistance were identified as reduced copy numbers of Suppressor of fused (SUFU) and increased copy numbers of GLI2 [34].

Typically, canonical activation of the Hedgehog signaling pathway occurs in cancers with mutations in PTCH1 and SMO, which are often responsive to SMO antagonists [37]. However, HHI resistance may occur with noncanonical Hedgehog pathway activation. Specifically, regulation and activity of GLI expression can occur in response to pathways other than $\mathrm{PTCH}$ and SMO, thereby reducing the efficacy of SMO antagonists [37]. Recently, a link between cytoskeletal regulators and Hedgehog pathway activation was identified in SMO inhibitorresistant $\mathrm{BCC}$ [38]. In these $\mathrm{SMO}$ inhibitor-resistant tumors, Rho-mediated activation of cytoskeletal F-actin to G-actin increased the Hedgehog signaling pathway activity through activation of the transcription factor serum response factor (SRF) and its coactivator megakaryoblastic leukemia-1 (MKL1) [38]. This increase in cellular SRF/ MKL1 increased nuclear accumulation of SRF/MKL1 and potentiated GLI-mediated Hedgehog pathway activation. This SRF-MKL1 cytoskeletal signaling axis represents a therapeutic target for HHI-resistant BCCs. Most SMO inhibitor-resistant BCCs analyzed contained activated MKL1 in the nucleus, and MKL1 inhibitors had antitumor activity in explants of resistant BCCs [38].

Another mechanism of $\mathrm{HHI}$ resistance involves BCC switching between canonical and noncanonical Hedgehog pathways [33, 39-41]. One study found that residual BCCs initiated a different transcriptional program compared with untreated BCCs, and this identified switch was linked to Wnt pathway activation. When vismodegib 
was combined with a Wnt pathway inhibitor, BCC tumor burden was reduced [40]. The Wnt pathway was observed as a mechanism for tumor cells to evade vismodegib and maintain a quiescent state independent of Hedgehog pathway signaling [40]. Further investigation of Wnt pathway-mediated evasion demonstrated that BCCs induced in a genetic mouse model of BCC expressed the leucine-rich repeat-containing G-protein coupled receptor Lgr5; upon drug withdrawal, the proliferation of these persistent, Lgr5-expressing cells promoted tumor regrowth [41]. Therefore, the Wnt-activated and Lgr5positive cells represent a type of resistance that may be considered tumor persistent rather than tumor progressive while patients are being treated with HHIs.

\section{Switching Hedgehog inhibitors in clinical studies and practice}

One approach to addressing $\mathrm{HHI}$ resistance in patients with $\mathrm{BCC}$ is switching agents after intrinsic or acquired resistance becomes apparent. Clinical study results and findings of case reports on switching HHIs are summarized in Table 1.

A patient with laBCC and acquired resistance to vismodegib was ultimately administered combination therapy with two other SMO inhibitors that bind to SMO on different sites than vismodegib and from each other. In this patient, daily dosing of sonidegib $200 \mathrm{mg}$ with concomitant pulse dosing of itraconazole $100 \mathrm{mg} /$ day caused substantial regression of BCC lesions after 3 months, with a noted further improvement after 8 months, and the treatment was well tolerated. This shows that a positive response with other SMO inhibitors after one has failed is possible [42].

Because phosphoinositide-3-kinase (PI3K) is implicated in SMO inhibitor resistance, the efficacy and safety of combination therapy with 28-day cycles of sonidegib $200 \mathrm{mg} /$ day and a pan-PI3K inhibitor, buparlisib, at a dose of $80 \mathrm{mg} /$ day, were investigated in an open-label, single-arm clinical trial. After a total of eight grade 3 AEs in $50 \%$ of the safety population, the study was terminated early. Overall, seven patients were evaluated for efficacy, five with previous HHI failure. This combination achieved an overall response rate of $14.3 \%$ and a disease control rate of $71 \%$; one patient had a partial response, and four patients remained with stable disease [43].

In contrast, nine patients with intrinsic or acquired resistance to vismodegib treatment received sonidegib $800 \mathrm{mg} /$ day. Overall, three patients had stable disease, one response was unknown, and five had PD, suggesting resistance to vismodegib conferred resistance to sonidegib [44]. This study was limited due to a relatively short treatment duration; of the nine patients in this trial, only one patient was treated beyond 14 weeks (total of 58 weeks), and some patients were treated for only 3 weeks. Therefore, this treatment period may not have been sufficient to achieve a measurable clinical response to sonidegib. In addition, this patient who had a D473H mutation in SMO was treated for 58 weeks and experienced disease progression. It has been shown in vitro that the affinity ( $\mathrm{pKi}$ ) of vismodegib and sonidegib for SMO decreased significantly compared with wildtype, from 8.32 to 5.95 (>100-fold) and from 7.68 to 6.91 , respectively, in the presence of a D473A mutation [45]. In contrast, in the presence of the E518A mutation, the $\mathrm{pKi}$ for vismodegib decreased to 6.68 and increased somewhat for sonidegib. Consequently, if resistance to vismodegib is due to a E518A mutation, treatment with sonidegib may still be effective. The affinity of the SMO antagonist LY2940680, taladegib, was not affected by the $\mathrm{D} 473 \mathrm{H}$ mutation, even though taladegib and vismodegib have 14 contact residues in common [45]. This supports the response to taladegib with a mutation rendering resistance to vismodegib [46]. Based on the SMO crystal structure, the computational docking of vismodegib onto SMO demonstrated that the locations of the SMO-W281, SMO-V321, SMO-I408 and SMO-C469 mutations are near the drug-binding pocket $[34,47]$. These mutations disrupt the hydrophobic pocket, interfere with the positioning of adjacent binding residues, change the conformation of the residues, and have steric effects on the binding pocket, respectively, to affect vismodegib binding [34]. Whether a patient who develops resistance to a specific HHI due to an SMO mutation will respond to a different HHI depends on the specific mutation, binding location, and whether a conformational change is generated to prevent drug binding in a direct or indirect manner. Along with patient sequencing data, these findings may help predict patient response to a subsequent $\mathrm{HHI}$ after failure of initial HHI treatment.

Vismodegib treatment in a patient diagnosed with Gorlin syndrome resulted in regression of cutaneous BCCs but disease progression of $\mathrm{mBCCs}$ in the lung, a response similar to that experienced with prior saridegib treatment. Consequently, since both HHIs produced a differential clinical response, with some tumors responding and others (metastatic) with no response, BCCs in patients with Gorlin syndrome may not be genetically identical [48]. Moreover, this patient's previous exposure of chemotherapy to treat testicular cancer may have conferred resistance to SMO inhibitors [48].

\section{Additional strategies for managing Hedgehog inhibitor resistance}

Combination therapy is a strategy to reduce the potential of acquired resistance. Use of combination therapy targeting different mechanisms of action may reduce the chance of acquired resistance while increasing efficacy. Several case reports and small analyses discuss the potential benefits of an HHI in combination with 
Table 1: Summary of clinical studies and case reports on switching Hedgehog inhibitors

\begin{tabular}{|c|c|c|c|c|c|}
\hline Publication & Type & Patient characteristics & Treatment & Efficacy results & Safety results \\
\hline Yoon et al. [42] & Case report & $\begin{array}{l}\text { - 87-year-old male } \\
\text { - Inoperable laBCC of ethmoid } \\
\text { sinus and brain } \\
\text { - Treated with vismodegib } \\
150 \mathrm{mg} \text { /day } 5 \text { years earlier; } \\
\text { acquired resistance after } \\
>1 \text { year, vismodegib was } \\
\text { discontinued } \\
\text { - Radiation therapy } \\
\text { - Recurrence after } 2 \text { years } \\
\text { - Progression on } 6 \text { months of } \\
\text { vismodegib } \\
\text { - Pembrolizumab ( } 3 \text { cycles) } \\
\text { resulted in further progression }\end{array}$ & $\begin{array}{l}\text { Sonidegib } 200 \mathrm{mg} / \\
\text { day }+ \text { itraconazole } \\
\text { pulse dosed at } \\
100 \mathrm{mg} / \text { day for } 2 \\
\text { weeks/rest for } 2 \\
\text { weeks, repeated } \\
\text { monthly }\end{array}$ & $\begin{array}{l}\text { - Significant improvement } \\
\text { after } 3 \text { months } \\
\text { - After } 8 \text { months, intracranial } \\
\text { lesion no longer visible, } \\
\text { intranasal and sinus lesions } \\
\text { stable/slightly improved }\end{array}$ & No major AEs \\
\hline Tran et al. [43] & $\begin{array}{l}\text { Clinical } \\
\text { study }\end{array}$ & $\begin{array}{ll}\text { - } & \text { laBCC or mBCC } \\
\text { - } & \text { Median (range) age at } \\
\text { enrollment, } 61 \text { (45-87) years } \\
\text { - } 5 \text { patients had received prior } \\
\text { HHIs (vismodegib, taladegib) }\end{array}$ & $\begin{array}{l}\text { Sonidegib } 200 \mathrm{mg} / \\
\text { day }+ \text { buparlisib } \\
80 \mathrm{mg} / \text { day, } 28 \text {-day } \\
\text { cycles }\end{array}$ & $\begin{array}{ll}\text { - } & \text { Median (range) follow-up, } 8 \\
& (0.5-20) \text { months } \\
\text { - } & 7 \text { evaluable patients } \\
\text { - } & \text { ORR: } 1 / 7(14.3 \%) \\
\text { - } & \text { PR/SD as best response: } 5 / 7 \\
& (71 \%)\end{array}$ & $\begin{array}{l}\text { Grade } 3 \text { TRAEs } 50 \% \\
\text { patients led to early } \\
\text { study termination }\end{array}$ \\
\hline $\begin{array}{l}\text { Zargari et al. } \\
\text { Dermatol Ther. } \\
2017\end{array}$ & Case report & $\begin{array}{l}\text { - 48-year-old male } \\
\text { - Infiltrative BCC on the nose } \\
\text { excised incompletely } \\
\text { - Recurrence and appearance } \\
\text { of new lesions treated with } \\
\text { radiation therapy } \\
\text { - Recurrent lesion improved with } \\
\text { imiquimod treatment } \\
\text { - Recurrent lesion infiltrated the } \\
\text { whole nose, visual limitation } \\
\text { Treated with itraconazole } \\
\text { twice daily for } 4 \text { months with } \\
\text { minimal effect }\end{array}$ & $\begin{array}{l}\text { Vismodegib } 150 \\
\mathrm{mg} / \text { day for } 3 \\
\text { consecutive } 28- \\
\text { day cycles }\end{array}$ & $\begin{array}{l}\text { - Significant decrease in size } \\
\text { and signs of healing at } 1 \\
\text { month, improved visual } \\
\text { movement } \\
\text { - No signs of recurrence } 8 \\
\text { months after treatment }\end{array}$ & No significant AEs \\
\hline Danial et al.[44] & $\begin{array}{l}\text { Clinical } \\
\text { study }\end{array}$ & $\begin{array}{l}\text { - Advanced BCC with } \\
\text { demonstrated intrinsic } \\
\text { or acquired resistance to } \\
\text { vismodegib } \\
\text { Mean (range) age, } 57.4 \text { (42-91) } \\
\text { years }\end{array}$ & $\begin{array}{l}\text { Sonidegib } 800 \mathrm{mg} / \\
\text { day, } 28 \text {-day cycles }\end{array}$ & $\begin{array}{l}\text { - Median (range) treatment } \\
\text { duration, } 6(3-58) \text { weeks } \\
\text { - } 5 / 9 \text { patients had PD within a } \\
\text { median of } 6 \text { weeks } \\
\text { - } 3 / 9 \text { patients had SD within a } \\
\text { median of } 4 \text { weeks } \\
\text { - } 1 \text { patient discontinued } \\
\text { treatment for grade } 3 \\
\text { rhabdomyolysis }\end{array}$ & $\begin{array}{l}\text { Grade } 3 \text { AEs: } \\
\text { rhabdomyolysis, } \\
\text { nausea, altered } \\
\text { mental status }\end{array}$ \\
\hline Zhu et al.[48] & Case report & $\begin{array}{l}\text { - Male in his } 50 \mathrm{~s} \\
\text { - Gorlin syndrome } \\
\text { - Multiple BCCs on the } \\
\text { head, neck, trunk, and all } 4 \\
\text { extremities } \\
\text { - Cutaneous lesions shrank with } \\
\text { saridegib } 130 \mathrm{mg} \text { /day } \\
\text { - Lung metastases were refractory } \\
\text { to saridegib } 130 \mathrm{mg} \text { /day }\end{array}$ & $\begin{array}{l}\text { Vismodegib } 150 \\
\mathrm{mg} \text { /day }\end{array}$ & $\begin{array}{l}\text { Vismodegib } 150 \mathrm{mg} / \text { day } \\
\text { resulted in further shrinkage } \\
\text { of cutaneous lesions } \\
\text { After } 4 \text { months of treatment, } \\
\text { lung metastases had } \\
\text { progressed }\end{array}$ & Not reported \\
\hline
\end{tabular}

Abbreviations: AE: adverse event; BCC: basal cell carcinoma; laBCC: locally advanced BCC; mBCC: metastatic BCC; ORR: overall response rate; PD: progressive disease; PR: partial response; SD: stable disease; TRAE: treatment-related adverse event.

radiotherapy, photodynamic therapy (PDT), or other HHIs [23, 49-55]. Administration of vismodegib 150 $\mathrm{mg} /$ day in combination with radiotherapy resulted in a complete response and near-complete skin closure of multiple massive BCCs on the torso of a man in his $50 \mathrm{~s}$ at 6 months following treatment [49]. In two patients who had recurrent advanced BCCs on the face, the combination of vismodegib $150 \mathrm{mg}$ /day and radiotherapy showed no evidence of PD at last follow-up (9-12 months) [54]. In a retrospective analysis with a median follow-up of 12.5 months, four patients with inoperable laBCC received vismodegib $150 \mathrm{mg} /$ day along with radiotherapy. Of the four patients, three had a persistent complete response, one was progression-free for 6 months, and all tolerated therapy well [53]. In an open-label pilot study of four male patients with multiple BCCs, patients were treated with combination therapy consisting of 3 continuous months of vismodegib $150 \mathrm{mg} /$ day in combination with three 
consecutive sessions of PDT with topical application of 20\% 5-aminolevulinic acid; results demonstrated a $90 \%$ complete response rate, a $10 \%$ partial response rate, and the treatment was well tolerated [50]. Combination HHI therapy with vismodegib $150 \mathrm{mg}$ /day and itraconazole $100 \mathrm{mg} /$ day for 4 months in a 71-year-old man with an invasive BCC led to a complete response and no clinical recurrence after treatment cessation at last follow-up of 18 months [51]. Five men with $\mathrm{mBCC}$ refractory to vismodegib or both vismodegib and sonidegib received arsenic trioxide $0.3 \mathrm{mg} / \mathrm{kg}$ daily for 5 days of a 28-day cycle and itraconazole $400 \mathrm{mg}$ /day on non-arsenic trioxide days. Three evaluable patients had stable disease after three cycles of treatment and one patient had PD [23].

Another strategy to reduce the likelihood of developing acquired resistance is upfront shorter duration treatment prior to surgery, which may help reduce the time for acquired resistance to develop. HHIs are being studied as neoadjuvant therapy to reduce lesion size prior to surgery to optimize outcomes, as well as to enable the possibility of surgical excision in candidates previously unsuitable for surgery [56-66]. With this strategy, the development of HHI resistance may be less likely, as patients who respond to initial treatment will be able to have their tumors removed. In an open-label clinical study evaluating the use of vismodegib as neoadjuvant to surgery in high-risk patients with BCC, the study authors noted a mean decrease from baseline in target tumor surgical defect area of $27 \%$ in patients treated with at least 3 months of vismodegib at $150 \mathrm{mg} /$ day [66]. Among eight patients in the trial who participated in a 2-year follow-up, neoadjuvant vismodegib reduced the surgical defect area from baseline by $34.8 \%$ and allowed for surgical clearance of the tumor with no recurrence at a mean follow-up of 22 months [62]. A retrospective chart review of patients who received $\mathrm{HHI}$ therapy for extensive $\mathrm{BCC}$ found reductions in tumor burden allowing for less extensive surgery than originally planned [65]. In addition, case studies report reductions in the size of BCCs prior to surgery with vismodegib therapy [58, 60, 64]: neoadjuvant vismodegib therapy decreased tumor size by at least $70 \%$ in patients with extensive BCCs $[61,63]$. For patients with periocular tumors, neoadjuvant vismodegib treatment has enabled less radical, eye-sparing surgery $[57,59]$.

Targeting downstream effectors of the Hedgehog pathway is being studied in a clinical trial as a potential means to overcome or to prevent HHI resistance, as this approach directly interferes with multiple resistance pathways [67-72]. The GLI transcription factors are a logical target, as they are thought to regulate multiple pro-tumorigenic signaling pathways [67]. Another, more recently identified, target is the dual-specificity-tyrosinephosphorylation-regulated kinase 1B (DYRK1B), which positively regulates GLI activity and can be inhibited by a small molecule inhibitor, DYRKi, in both SMO inhibitorsensitive and -resistant cells [70]. Another small molecule inhibitor, 4SC-202, blocks Hedgehog/GLI signaling by targeting class 1 histone deacetylases (HDAC) in SMO inhibitor-sensitive and -resistant cells and is being studied clinically [69]. A new small molecule combinatorial SMO-HDAC antagonist that simultaneously inhibits SMO and GLI activity, IHR-SAHA, shows activity in SMO inhibitor-sensitive and -resistant cells. Epigenetic targeting is also being investigated, as bromo and extra C-terminal (BET) bromodomain proteins that regulate GLI transcription are inhibited by JQ1, a small molecule inhibitor of BRD4, in both SMO inhibitor-sensitive and -resistant cells [72].

Findings of a retrospective chart review and several case studies suggest targeting of programmed cell death protein 1 (PD-1) may be beneficial in patients with advanced $\mathrm{BCC}$ [73-78]. The chart review compared the incidence of BCC and squamous cell carcinoma among patients diagnosed with metastatic melanoma and treated with anti-PD-1 therapies, patients treated with other melanoma therapies, and patients with similar risk factors as a control group. The incidence of BCC was significantly lower among patients with melanoma receiving anti-PD-1 therapies vs controls, suggesting anti-PD-1 therapies may suppress BCC [74]. Characterization of PD-1 and PDL1 expression patterns among BCC samples show PDL1 expression on $22 \%$ of tumor cells and $82 \%$ of tumor infiltrating lymphocytes and macrophages, suggesting that treatment with immune checkpoint inhibitors may be effective in BCC [77]. Notably, several case reports of patients with laBCC or $\mathrm{mBCC}$ and $\mathrm{HHI}$ resistance have shown dramatic responses to treatment with either pembrolizumab or nivolumab [73, 76-78]. Although in one case, the nivolumab response was accompanied by the appearance of new superficial BCCs that could be treated with excision [76]. As of June 2021, three ongoing clinical trials of PD-1 inhibitors in patients with advanced BCC were registered with https://www.clinicaltrials.gov/ (NCT03132636, NCT03521830, and NCT04323202). One of the trials uses the recently approved cemiplimab (Libtayo $^{\circledR}$, Regeneron Pharmaceuticals Inc., Tarrytown, NY), a PD-1 inhibitor indicated to treat patients with laBCC or mBCC previously treated with an HHI or for whom an HHI is not appropriate [79]. The phase 2 data from this single-arm, open-label trial of cemiplimab demonstrated clinically meaningful and durable responses in patients with laBCC who have experienced PD on HHI therapy or were intolerant of prior HHI therapy. The ORR for patients with laBCC was $31 \%(n=84 ; 95 \% \mathrm{CI}, 21.0 \%-$ $42.0 \%$ ), with estimated duration of response exceeding 1 year in $85 \%$ of responders $(95 \% \mathrm{CI}, 60.5 \%-95.0 \%)$, and an estimated PFS of 19.0 months (95\% CI, 44.3\%-67.0\%) [80]. Consequently, in patients with advanced BCC and resistance to HHI treatment, cemiplimab may provide these patients with an alternative treatment option.

Interestingly, in a study of three patients with laBCC who had complete response following treatment 
with vismodegib that was clinically and histologically confirmed, and then relapsed after discontinuing treatment, mutational analysis of the coding regions of sequenced genes in relapsed tumors was not significantly changed compared with tumor analyses prior to vismodegib treatment [81]. These results demonstrate that tumor relapse following vismodegib discontinuation retains the same mutational pattern as the baseline tumor, suggesting these tumors may be eligible for treatment rechallenge [81].

Overall HHI resistance, either intrinsic or acquired, continues to be a challenge in a subset of patients with advanced BCC, despite HHIs efficacy and tolerability in most patients. Mechanisms of resistance to HHIs include mutations in SMO, noncanonical cell identity switching resulting in resistant tumor cells, and non-canonical pathway crosstalk that may activate the Hedgehog pathway. Management of patients with HHI resistance can include switching HHI agents, combination therapy of HHIs and radiotherapy, photodynamic therapy, and targeting specific downstream effectors of the Hedgehog signaling pathway. Although these approaches to $\mathrm{HHI}$ resistance may be effective in some patients, further identification of biomarkers of resistance is needed. Identification of biomarkers of resistance or response would have the potential to improve the therapeutic efficacy of HHIs by personalizing treatment, and should be a future research goal for the treatment of advanced BCC.

\section{Abbreviations}

AE: adverse event; BCC: basal cell carcinoma; BET: bromo and extra C-terminal; CI: confidence interval; DYRK1B: dual-specificity-tyrosine-phosphorylationregulated kinase 1B; FDA: Food and Drug Administration; HDAC: histone deacetylases; HHI: Hedgehog pathway inhibitors; laBCC: locally advanced BCC; mBCC: metastatic BCC; MKL1: megakaryoblastic leukemia-1; ORR: objective response rate; $\mathrm{PD}$ : progressive disease; $\mathrm{PD}-1$ : programmed cell death protein 1; PDT: photodynamic therapy; PFS: progression-free survival; PI3K: phosphoinositide-3kinase; pKi: affinity; PTCH1: patched homologue 1; SMO: Smoothened homologue; SRF: serum response factor; SUFU: suppressor of fused; TEAE: treatment-emergent AE.

\section{Author contributions}

All listed authors meet the criteria for authorship set forth by the International Committee for Medical Journal Editors and have significantly contributed to, seen, and approved the final submitted version of the manuscript.

\section{ACKNOWLEDGMENTS}

Writing and editorial assistance provided by Zehra Gundogan, VMD, AlphaBioCom, LLC, and funded by Sun Pharmaceutical Industries, Inc.

\section{CONFLICTS OF INTEREST}

HQ Doan, L Chen, Z Nawas, and HH Lee have nothing to disclose. S Silapunt has participated in advisory boards and received honoraria from Sun Pharmaceutical Industries, Inc. MR Migden has participated in advisory boards and received honoraria from Genentech; Novartis; Sun Pharmaceutical Industries, Inc.; and Regeneron.

\section{FUNDING}

Sun Pharmaceutical Industries, Inc. provided funding for writing and editorial assistance.

\section{REFERENCES}

1. Lear JT, Corner C, Dziewulski P, Fife K, Ross GL, Varma $\mathrm{S}$, Harwood CA. Challenges and new horizons in the management of advanced basal cell carcinoma: a UK perspective. Br J Cancer. 2014; 111:1476-81. https://doi. org/10.1038/bjc.2014.270. [ubMed]

2. Marzuka AG, Book SE. Basal cell carcinoma: pathogenesis, epidemiology, clinical features, diagnosis, histopathology, and management. Yale J Biol Med. 2015; 88:167-79. [PubMed]

3. Cameron MC, Lee E, Hibler BP, Barker CA, Mori S, Cordova M, Nehal KS, Rossi AM. Basal cell carcinoma: epidemiology; pathophysiology; clinical and histological subtypes; and disease associations. J Am Acad Dermatol. 2019; 80:303-17. https://doi.org/10.1016/j. jaad.2018.03.060. [PubMed]

4. Kim JYS, Kozlow JH, Mittal B, Moyer J, Olencki T, Rodgers $\mathrm{P}$, and Work Group, and Invited Reviewers. Guidelines of care for the management of basal cell carcinoma. J Am Acad Dermatol. 2018; 78:540-59. https:// doi.org/10.1016/i.jaad.2017.10.006. [PubMed]

5. Peris K, Fargnoli MC, Garbe C, Kaufmann R, Bastholt L, Seguin NB, Bataille V, Marmol VD, Dummer R, Harwood CA, Hauschild A, Höller C, Haedersdal M, et al, and European Dermatology Forum (EDF), the European Association of Dermato-Oncology (EADO) and the European Organization for Research and Treatment of Cancer (EORTC). Diagnosis and treatment of basal cell carcinoma: European consensus-based interdisciplinary guidelines. Eur J Cancer. 2019; 118:10-34. https://doi. org/10.1016/j.ejca.2019.06.003. [PubMed]

6. Amici JM, Battistella M, Beylot-Barry M, Chatellier A, Dalac-Ra S, Dreno B, Falandry C, Froget N, Giacchero D, Grob JJ, Guerreschir P, Leccia MT, Malard O, et al. Defining and recognising locally advanced basal cell carcinoma. Eur J Dermatol. 2015; 25:586-94. https://doi. org/10.1684/ejd.2015.2641. [PubMed]

7. Abidi A. Hedgehog signaling pathway: a novel target for cancer therapy: vismodegib, a promising therapeutic option in treatment of basal cell carcinomas. Indian J Pharmacol. 
2014; 46:3-12. https://doi.org/10.4103/0253-7613.124884. [PubMed]

8. Raffel C, Jenkins RB, Frederick L, Hebrink D, Alderete B, Fults DW, James CD. Sporadic medulloblastomas contain PTCH mutations. Cancer Res. 1997; 57:842-45. [PubMed]

9. Scales SJ, de Sauvage FJ. Mechanisms of Hedgehog pathway activation in cancer and implications for therapy. Trends Pharmacol Sci. 2009; 30:303-12. https://doi. org/10.1016/j.tips.2009.03.007. [ubMed]

10. Epstein EH. Basal cell carcinomas: attack of the hedgehog. Nat Rev Cancer. 2008; 8:743-54. https://doi.org/10.1038/ nrc2503. [PubMed]

11. Odomzo (sonidegib capsules). Full Prescribing Information. Sun Pharmaceutical Industries, Inc., Cranbury, NJ, USA. https://www.accessdata.fda.gov/drugsatfda docs/ label/2019/205266s006lbl.pdf.

12. Erivedge (vismodegib capsules). Full prescribing information. Genentech, San Francisco, CA, USA. https://www.accessdata.fda.gov/drugsatfda_docs/ label/2020/203388s016lbl.pdf.

13. Sekulic A, Migden MR, Oro AE, Dirix L, Lewis KD, Hainsworth JD, Solomon JA, Yoo S, Arron ST, Friedlander PA, Marmur E, Rudin CM, Chang AL, et al. Efficacy and safety of vismodegib in advanced basal-cell carcinoma. N Engl J Med. 2012; 366:2171-79. https://doi.org/10.1056/ NEJMoa1113713. [PubMed]

14. Basset-Séguin N, Hauschild A, Kunstfeld R, Grob J, Dréno B, Mortier L, Ascierto PA, Licitra L, Dutriaux C, Thomas L, Meyer N, Guillot B, Dummer R, et al. Vismodegib in patients with advanced basal cell carcinoma: Primary analysis of STEVIE, an international, open-label trial. Eur J Cancer. 2017; 86:334-48. https://doi.org/10.1016/j. ejca.2017.08.022. [PubMed]

15. Dréno B, Kunstfeld R, Hauschild A, Fosko S, Zloty D, Labeille B, Grob JJ, Puig S, Gilberg F, Bergström D, Page DR, Rogers G, Schadendorf D. Two intermittent vismodegib dosing regimens in patients with multiple basal-cell carcinomas (MIKIE): a randomised, regimencontrolled, double-blind, phase 2 trial. Lancet Oncol. 2017; 18:404-12. https://doi.org/10.1016/S1470-2045(17)300724. [ㄹbMed]

16. Dummer R, Guminksi A, Gutzmer R, Lear JT, Lewis KD, Chang ALS, Combemale P, Dirix L, Kaatz M, Kudchadkar R, Loquai C, Plummer R, Schulze HJ, et al. Long-term efficacy and safety of sonidegib in patients with advanced basal cell carcinoma: 42-month analysis of the phase II randomized, double-blind BOLT study. Br J Dermatol. 2020; 182:1369-1378. https://doi.org/10.1111/bjd.18552. [PubMed]

17. Dummer R, Guminski A, Gutzmer R, Dirix L, Lewis KD, Combemale P, Herd RM, Kaatz M, Loquai C, Stratigos AJ, Schulze HJ, Plummer R, Gogov S, et al. The 12-month analysis from Basal Cell Carcinoma Outcomes with LDE225 Treatment (BOLT): A phase II, randomized, double-blind study of sonidegib in patients with advanced basal cell carcinoma. J Am Acad Dermatol. 2016; 75:113125.e5. https://doi.org/10.1016/j.jaad.2016.02.1226. [PubMed]

18. Lear JT, Migden MR, Lewis KD, Chang ALS, Guminski A, Gutzmer R, Dirix L, Combemale P, Stratigos A, Plummer R, Castro H, Yi T, Mone M, et al. Long-term efficacy and safety of sonidegib in patients with locally advanced and metastatic basal cell carcinoma: 30-month analysis of the randomized phase 2 BOLT study. J Eur Acad Dermatol Venereol. 2018; 32:372-381. https://doi.org/10.1111/ jdv.14542. [PubMed]

19. Migden MR, Guminski A, Gutzmer R, Dirix L, Lewis KD, Combemale P, Herd RM, Kudchadkar R, Trefzer U, Gogov S, Pallaud C, Yi T, Mone M, et al. Treatment with two different doses of sonidegib in patients with locally advanced or metastatic basal cell carcinoma (BOLT): a multicentre, randomised, double-blind phase 2 trial. Lancet Oncol. 2015; 16:716-28. https://doi.org/10.1016/S14702045(15)70100-2. [PubMed]

20. Epstein EH, Lear J, Saldanha G, Tang JY, Harwood C. Hedgehog pathway inhibition by topical patidegib to reduce BCC burden in patients with basal cell nevus (Gorlin) syndrome. J Clin Oncol. 2018; 36:e21626-e21626. https:// doi.org/10.1200/JCO.2018.36.15 suppl.e21626.

21. Gutzmer R, Solomon JA. Hedgehog Pathway Inhibition for the Treatment of Basal Cell Carcinoma. Target Oncol. 2019; 14:253-267. https://doi.org/10.1007/s11523-019-00648-2. [PubMed]

22. Kim J, Tang JY, Gong R, Kim J, Lee JJ, Clemons KV, Chong CR, Chang KS, Fereshteh M, Gardner D, Reya T, Liu JO, Epstein EH, et al. Itraconazole, a commonly used antifungal that inhibits Hedgehog pathway activity and cancer growth. Cancer Cell. 2010; 17:388-99. https://doi. org/10.1016/j.ccr.2010.02.027. [PubMed]

23. Ally MS, Ransohoff K, Sarin K, Atwood SX, Rezaee M, Bailey-Healy I, Kim J, Beachy PA, Chang AL, Oro A, Tang JY, Colevas AD. Effects of Combined Treatment With Arsenic Trioxide and Itraconazole in Patients With Refractory Metastatic Basal Cell Carcinoma. JAMA Dermatol. 2016; 152:452-6. https://doi.org/10.1001/ jamadermatol.2015.5473. [PubMed]

24. Hansel G, Tchernev G, Chokoeva AA, Lotti T, Schönlebe J, Wollina U. Failure of vismodegib in advanced Basal cell carcinoma. J Biol Regul Homeost Agents. 2015; 29:11-13. [PubMed]

25. Nayyar PM, Chang ALS, Sarin K, Ratner D. Unique Tumor Heterogeneity Within a Single Locally Advanced Basal Cell Carcinoma Resulting in a Partial Response Despite Continuous Vismodegib Treatment. Dermatol Surg. 2019; 45:608-10. https://doi.org/10.1097/ DSS.0000000000001607. [PubMed]

26. Sinx KAE, Roemen G, van Zutven V, Janssen R, Speel EM, Steijlen PM, van Geel M, Mosterd K. Vismodegib-resistant basal cell carcinomas in basal cell nevus syndrome: Clinical approach and genetic analysis. JAAD Case Rep. 
2018; 4:408-11. https://doi.org/10.1016/i.jdcr.2017.11.011. [PubMed]

27. Papastefanou VP, René C. Secondary Resistance to Vismodegib After Initial Successful Treatment of Extensive Recurrent Periocular Basal Cell Carcinoma with Orbital Invasion. Ophthalmic Plast Reconstr Surg. 2017 (Suppl 1); 33:S68-70. https://doi.org/10.1097/iop.0000000000000565. [PubMed]

28. Meani RE, Lim SW, Chang AL, Kelly JW. Emergence of chemoresistance in a metastatic basal cell carcinoma patient after complete response to hedgehog pathway inhibitor vismodegib (GDC-0449). Australas J Dermatol. 2014; 55:218-21. https://doi.org/10.1111/ajd.12196. [PubMed]

29. Soura E, Plaka M, Dessinioti C, Syrigos K, Stratigos AJ. Can hair re-growth be considered an early clinical marker of treatment resistance to Hedgehog inhibitors in patients with advanced basal cell carcinoma? A report of two cases. J Eur Acad Dermatol Venereol. 2016; 30:1726-1729. https://doi. org/10.1111/jdv.13754. [PubMed]

30. Chiang A, Jaju PD, Batra P, Rezaee M, Epstein EH Jr, Tang JY, Sarin KY. Genomic Stability in Syndromic Basal Cell Carcinoma. J Invest Dermatol. 2018; 138:1044-1051. https://doi.org/10.1016/i.jid.2017.09.048. [PubMed]

31. Shimizu Y, Ishii T, Ogawa K, Sasaki S, Matsui H, Nakayama M. Biochemical characterization of smoothened receptor antagonists by binding kinetics against drugresistant mutant. Eur J Pharmacol. 2015; 764:220-227. https://doi.org/10.1016/j.ejphar.2015.05.062. [PubMed]

32. Liu M, Liang G, Zheng H, Zheng N, Ge H, Liu W. Triazoles bind the C-terminal domain of SMO: Illustration by docking and molecular dynamics simulations the binding between SMO and triazoles. Life Sci. 2019; 217:222-228. https:// doi.org/10.1016/j.lfs.2018.12.012. [PubMed]

33. Zhao X, Ponomaryov T, Ornell KJ, Zhou P, Dabral SK, Pak E, Li W, Atwood SX, Whitson RJ, Chang AL, Li J, Oro AE, Chan JA, et al. RAS/MAPK Activation Drives Resistance to Smo Inhibition, Metastasis, and Tumor Evolution in Shh Pathway-Dependent Tumors. Cancer Res. 2015; 75:362335. https://doi.org/10.1158/0008-5472.CAN-14-2999-T. [PubMed]

34. Sharpe HJ, Pau G, Dijkgraaf GJ, Basset-Seguin N, Modrusan Z, Januario T, Tsui V, Durham AB, Dlugosz AA, Haverty PM, Bourgon R, Tang JY, Sarin KY, et al. Genomic analysis of smoothened inhibitor resistance in basal cell carcinoma. Cancer Cell. 2015; 27:327-41. https://doi. org/10.1016/j.ccell.2015.02.001. [PubMed]

35. Pricl S, Cortelazzi B, Dal Col V, Marson D, Laurini E, Fermeglia M, Licitra L, Pilotti S, Bossi P, Perrone F. Smoothened (SMO) receptor mutations dictate resistance to vismodegib in basal cell carcinoma. Mol Oncol. 2015; 9:389-97. https://doi.org/10.1016/j.molonc.2014.09.003. [PubMed]

36. Atwood SX, Sarin KY, Whitson RJ, Li JR, Kim G, Rezaee M, Ally MS, Kim J, Yao C, Chang AL, Oro AE, Tang JY. Smoothened variants explain the majority of drug resistance in basal cell carcinoma. Cancer Cell. 2015; 27:342-53. https://doi.org/10.1016/j.ccell.2015.02.002. [PubMed]

37. Pietrobono S, Gagliardi S, Stecca B. Non-canonical Hedgehog Signaling Pathway in Cancer: Activation of GLI Transcription Factors Beyond Smoothened. Front Genet. 2019; 10:556. https://doi.org/10.3389/fgene.2019.00556. [PubMed]

38. Whitson RJ, Lee A, Urman NM, Mirza A, Yao CY, Brown AS, Li JR, Shankar G, Fry MA, Atwood SX, Lee EY, Hollmig ST, Aasi SZ, et al. Noncanonical hedgehog pathway activation through SRF-MKL1 promotes drug resistance in basal cell carcinomas. Nat Med. 2018; 24:271281. https://doi.org/10.1038/nm.4476. [PubMed]

39. Kuonen F, Huskey NE, Shankar G, Jaju P, Whitson RJ, Rieger KE, Atwood SX, Sarin KY, Oro AE. Loss of Primary Cilia Drives Switching from Hedgehog to Ras/ MAPK Pathway in Resistant Basal Cell Carcinoma. J Invest Dermatol. 2019; 139:1439-1448. https://doi.org/10.1016/j. jid.2018.11.035. [PubMed]

40. Biehs B, Dijkgraaf GJP, Piskol R, Alicke B, Boumahdi S, Peale F, Gould SE, de Sauvage FJ. A cell identity switch allows residual BCC to survive Hedgehog pathway inhibition. Nature. 2018; 562:429-33. https://doi. org/10.1038/s41586-018-0596-y. [PubMed]

41. Sánchez-Danés A, Larsimont JC, Liagre M, MuñozCouselo E, Lapouge G, Brisebarre A, Dubois C, Suppa M, Sukumaran V, Del Marmol V, Tabernero J, Blanpain C. A slow-cycling LGR5 tumour population mediates basal cell carcinoma relapse after therapy. Nature. 2018; 562:434-38. https://doi.org/10.1038/s41586-018-0603-3. [PubMed]

42. Yoon J, Apicelli AJ 3rd, Pavlopoulos TV. Intracranial regression of an advanced basal cell carcinoma using sonidegib and itraconazole after failure with vismodegib. JAAD Case Rep. 2017; 4:10-12. https://doi.org/10.1016/j. jdcr.2017.11.001. [PubMed]

43. Tran DC, Moffat A, Brotherton R, Pague A, Zhu GA, Chang ALS. An exploratory open-label, investigator-initiated study to evaluate the efficacy and safety of combination sonidegib and buparlisib for advanced basal cell carcinomas. J Am Acad Dermatol. 2018; 78:1011-13.e3. https://doi. org/10.1016/i.jaad.2017.11.031. [PubMed]

44. Danial C, Sarin KY, Oro AE, Chang AL. An InvestigatorInitiated Open-Label Trial of Sonidegib in Advanced Basal Cell Carcinoma Patients Resistant to Vismodegib. Clin Cancer Res. 2016; 22:1325-9. https://doi.org/10.1158/10780432.CCR-15-1588. [PubMed]

45. Chen L, Aria AB, Silapunt S, Lee HH, Migden MR. Treatment of advanced basal cell carcinoma with sonidegib: perspective from the 30-month update of the BOLT trial. Future Oncol. 2018; 14:515-25. https://doi.org/10.2217/ fon-2017-0457. [PubMed]

46. Wang C, Wu H, Evron T, Vardy E, Han GW, Huang XP, Hufeisen SJ, Mangano TJ, Urban DJ, Katritch V, Cherezov V, Caron MG, Roth BL, Stevens RC. Structural basis for Smoothened receptor modulation and chemoresistance to 
anticancer drugs. Nat Commun. 2014; 5:4355. https://doi. org/10.1038/ncomms5355. [PubMed]

47. Wang C, Wu H, Katritch V, Han GW, Huang XP, Liu W, Siu FY, Roth BL, Cherezov V, Stevens RC. Structure of the human smoothened receptor bound to an antitumour agent. Nature. 2013; 97:338-43. https://doi.org/10.1038/ nature12167. [PubMed]

48. Zhu GA, Li AS, Chang AL. Patient with Gorlin syndrome and metastatic basal cell carcinoma refractory to smoothened inhibitors. JAMA Dermatol. 2014; 150:877-9. https://doi.org/10.1001/jamadermatol.2013.8744. [PubMed]

49. Franco AI, Eastwick G, Farah R, Heyboer M, Lee M, Aridgides P. Upfront Radiotherapy with Concurrent and Adjuvant Vismodegib Is Effective and Well-Tolerated in a Patient with Advanced, Multifocal Basal Cell Carcinoma. Case Rep Dermatol Med. 2018; 2018:2354146. https://doi. org/10.1155/2018/2354146. [PubMed]

50. Rizzo JM, Segal RJ, Zeitouni NC. Combination vismodegib and photodynamic therapy for multiple basal cell carcinomas. Photodiagnosis Photodyn Ther. 2018; 21:5862. https://doi.org/10.1016/j.pdpdt.2017.10.028. [PubMed]

51. Yang X, Dinehart MS. Triple Hedgehog Pathway Inhibition for Basal Cell Carcinoma. J Clin Aesthet Dermatol. 2017; 10:47-49. [PubMed]

52. Block AM, Alite F, Diaz AZ, Borrowdale RW, Clark JI, Choi M. Combination Trimodality Therapy Using Vismodegib for Basal Cell Carcinoma of the Face. Case Rep Oncol Med. 2015; 2015:827608. https://doi.org/10.1155/2015/827608. [PubMed]

53. Schulze B, Meissner M, Ghanaati S, Burck I, Rödel C, Balermpas P. Hedgehog pathway inhibitor in combination with radiation therapy for basal cell carcinomas of the head and neck : First clinical experience with vismodegib for locally advanced disease. Strahlenther Onkol. 2016; 192:2531. https://doi.org/10.1007/s00066-015-0902-7. [PubMed]

54. Pollom EL, Bui TT, Chang AL, Colevas AD, Hara WY. Concurrent Vismodegib and Radiotherapy for Recurrent, Advanced Basal Cell Carcinoma. JAMA Dermatol. 2015; 151:998-1001. https://doi.org/10.1001/ jamadermatol.2015.0326. [PubMed]

55. Raleigh DR, Algazi A, Arron ST, Neuhaus IM, Yom SS. Induction Hedgehog pathway inhibition followed by combined-modality radiotherapy for basal cell carcinoma. Br J Dermatol. 2015; 173:544-6. https://doi.org/10.1111/ bjd.13748. [PubMed]

56. Velleman J, Kaarela O, Vranckx JJ. Treatment of basal cell carcinoma with vismodegib: future or present? Acta Chir Belg. 2021; 121:198-203. https://doi.org/10.1080/0001545 8.2019.1658943. [PubMed]

57. Sagiv O, Nagarajan P, Ferrarotto R, Kandl TJ, Thakar SD, Glisson BS, Altan M, Esmaeli B. Ocular preservation with neoadjuvant vismodegib in patients with locally advanced periocular basal cell carcinoma. $\mathrm{Br} \mathrm{J}$ Ophthalmol. 2019; 103:775-780. https://doi.org/10.1136/ bjophthalmol-2018-312277. [PubMed]
58. Orduz Robledo M, Lebas E, Reginster MA, Baghaie M, Groves S, Nikkels AF. Giant morphea-form basal cell carcinoma of the umbilicus: Successful debulking with vismodegib. Rare Tumors. 2018; 10:2036361318772938. https://doi.org/10.1177/2036361318772938. [PubMed]

59. Wong KY, Fife K, Lear JT, Price RD, Durrani AJ. Vismodegib for Locally Advanced Periocular and Orbital Basal Cell Carcinoma: A Review of 15 Consecutive Cases. Plast Reconstr Surg Glob Open. 2017; 5:e1424. https://doi. org/10.1097/GOX.0000000000001424. [PubMed]

60. Tang N, Ratner D. Implementation of Systemic Hedgehog Inhibitors in Daily Practice as Neoadjuvant Therapy. J Natl Compr Canc Netw. 2017; 15:537-543. https://doi. org/10.6004/incen.2017.0051. [PubMed]

61. Paulsen JF, Øregaard JS, Nielsen AL, Gehl J, Venzo A. Vismodegib and surgery combined - effective treatment of locally advanced basal cell carcinoma. Acta Oncol. 2016; 55:1492-94. $\quad$ https://doi.org/10.1080/028418 6x.2016.1206212. [PubMed]

62. Kwon GP, Ally MS, Bailey-Healy I, Oro AE, Kim J, Chang AL, Aasi S, Tang JY. Update to an open-label clinical trial of vismodegib as neoadjuvant before surgery for high-risk basal cell carcinoma (BCC). J Am Acad Dermatol. 2016; 75:2135. https://doi.org/10.1016/j.jaad.2016.02.1235. [PubMed]

63. Sand M, Bechara FG, Skrygan M, Sand D, Gambichler T, Bromba M, Stockfleth E, Hessam S. Mutation Scanning of D1705 and D1709 in the RNAse IIIb Domain of MicroRNA Processing Enzyme Dicer in Cutaneous Melanoma. Pathol Oncol Res. 2016; 22:639-41. https://doi.org/10.1007/ s12253-015-0034-5. [PubMed]

64. Alcalay J, Tauber G, Fenig E, Hodak E. Vismodegib as a neoadjuvant treatment to Mohs surgery for aggressive basal cell carcinoma. J Drugs Dermatol. 2015; 14:219-23. [PubMed]

65. Ching JA, Curtis HL, Braue JA, Kudchadkar RR, Mendoza TI, Messina JL, Cruse CW, Smith DJ Jr, Harrington MA. The impact of neoadjuvant hedgehog inhibitor therapy on the surgical treatment of extensive basal cell carcinoma. Ann Plast Surg. 2015; 74 (Suppl 4):S193-97. https://doi. org/10.1097/SAP.0000000000000452. [PubMed]

66. Ally MS, Aasi S, Wysong A, Teng C, Anderson E, BaileyHealy I, Oro A, Kim J, Chang AL, Tang JY. An investigatorinitiated open-label clinical trial of vismodegib as a neoadjuvant to surgery for high-risk basal cell carcinoma. J Am Acad Dermatol. 2014; 71:904-911.e1. https://doi. org/10.1016/i.jaad.2014.05.020. [ [ PubMed]

67. Didiasova M, Schaefer L, Wygrecka M. Targeting GLI Transcription Factors in Cancer. Molecules. 2018; 23:1003. https://doi.org/10.3390/molecules23051003. [PubMed]

68. Fan CW, Yarravarapu N, Shi H, Kulak O, Kim J, Chen C, Lum L. A synthetic combinatorial approach to disabling deviant Hedgehog signaling. Sci Rep. 2018; 8:1133. https:// doi.org/10.1038/s41598-018-19408-9. [PubMed]

69. Gruber W, Peer E, Elmer DP, Sternberg C, Tesanovic S, Del Burgo P, Coni S, Canettieri G, Neureiter D, Bartz R, 
Kohlhof H, Vitt D, Aberger F. Targeting class I histone deacetylases by the novel small molecule inhibitor 4SC-202 blocks oncogenic hedgehog-GLI signaling and overcomes smoothened inhibitor resistance. Int J Cancer. 2018; 142:968-975. https://doi.org/10.1002/ijc.31117. [PubMed]

70. Gruber W, Hutzinger M, Elmer DP, Parigger T, Sternberg C, Cegielkowski L, Zaja M, Leban J, Michel S, Hamm $\mathrm{S}$, Vitt D, Aberger F. DYRK1B as therapeutic target in Hedgehog/GLI-dependent cancer cells with Smoothened inhibitor resistance. Oncotarget. 2016; 7:7134-48. https:// doi.org/10.18632/oncotarget.6910. [PubMed]

71. Li B, Fei DL, Flaveny CA, Dahmane N, Baubet V, Wang Z, Bai F, Pei XH, Rodriguez-Blanco J, Hang B, Orton D, Han L, Wang B, et al. Pyrvinium attenuates Hedgehog signaling downstream of smoothened. Cancer Res. 2014; 74:4811-21. https://doi.org/10.1158/0008-5472.CAN-140317. [PubMed]

72. Tang Y, Gholamin S, Schubert S, Willardson MI, Lee A, Bandopadhayay P, Bergthold G, Masoud S, Nguyen B, Vue $\mathrm{N}$, Balansay B, Yu F, Oh S, et al. Epigenetic targeting of Hedgehog pathway transcriptional output through BET bromodomain inhibition. Nat Med. 2014; 20:732-40. https://doi.org/10.1038/nm.3613. [PubMed]

73. Tsai KK, Khurana N, McCalmont T, Daud A, Bastian B, Yeh I. PTCH1 Mutation in a Patient With Metastatic Undifferentiated Carcinoma With Clear Cell Change. J Natl Compr Canc Netw. 2019; 17:778-783. https://doi. org/10.6004/jnccn.2019.7313. [PubMed]

74. Zhao CY, Hwang SJE, Anforth R, Carlos G, Chou S, Carlino M, Fernández-Peñas P. Incidence of Basal Cell Carcinoma and Squamous Cell Carcinoma in Patients on Antiprogrammed Cell Death-1 Therapy for Metastatic Melanoma. J Immunother. 2018; 41:343-49. https://doi. org $/ 10.1097 / \mathrm{cji} .0000000000000237$. [PubMed]

75. Fischer S, Hasan Ali O, Jochum W, Kluckert T, Flatz L, Siano M. Anti-PD-1 Therapy Leads to Near-Complete Remission in a Patient with Metastatic Basal Cell Carcinoma. Oncol Res Treat. 2018; 41:391-394. https:// doi.org/10.1159/000487084. [PubMed]

76. Cohen PR, Kato S, Goodman AM, Ikeda S, Kurzrock R. Appearance of New Cutaneous Superficial Basal Cell
Carcinomas during Successful Nivolumab Treatment of Refractory Metastatic Disease: Implications for Immunotherapy in Early Versus Late Disease. Int J Mol Sci. 2017; 18:1663. https://doi.org/10.3390/ijms18081663. [PubMed]

77. Lipson EJ, Lilo MT, Ogurtsova A, Esandrio J, Xu H, Brothers P, Schollenberger M, Sharfman WH, Taube JM. Basal cell carcinoma: PD-L1/PD-1 checkpoint expression and tumor regression after PD-1 blockade. J Immunother Cancer. 2017; 5:23. https://doi.org/10.1186/s40425-0170228-3. [PubMed]

78. Ikeda S, Goodman AM, Cohen PR, Jensen TJ, Ellison CK, Frampton G, Miller V, Patel SP, Kurzrock R. Metastatic basal cell carcinoma with amplification of PD-L1: exceptional response to anti-PD1 therapy. NPJ Genom Med. 2016; 1:16037. https://doi.org/10.1038/npjgenmed.2016.37. [PubMed]

79. Libtayo (cemiplimab-rwlc). Full Prescribing Information. Regeneron Pharmaceuticals, Inc., Tarrytown, NY, USA. https://www.accessdata.fda.gov/drugsatfda_docs/ label/2021/761097s0071bl.pdf.

80. Stratigos A, Sekulic A, Peris K, Bechter O, Dutriaux C, Kaatz M, Lewis K, Basset-Seguin N, Chang A, Dalle S, Fernandez-Orland A, Licitra L, Robert C, et al. LBA47 Primary analysis of phase II results for cemiplimab in patients (pts) with locally advanced basal cell carcinoma (laBCC) who progress on or are intolerant to hedgehog inhibitors (HHIs). Ann Oncol. 2020; 31:S1175-76.

81. Ighilahriz M, Benfodda M, Sharpe H, Soufir N, Mourah S, Dumaz N, Battistella M, Savina A, Bouquet F, Nikolaev S, Basset-Seguin N. Vismodegib resistant mutations are not selected in multifocal relapses of locally advanced basal cell carcinoma after vismodegib discontinuation. J Eur Acad Dermatol Venereol. 2019; 33:e422-24. https://doi. org/10.1111/jdv.15741. [PubMed]

82. Cortes JE, Gutzmer R, Kieran MW, Solomon JA. Hedgehog signaling inhibitors in solid and hematological cancers. Cancer Treat Rev. 2019; 76:41-50. https://doi.org/10.1016/j. ctrv.2019.04.005. [PubMed] 